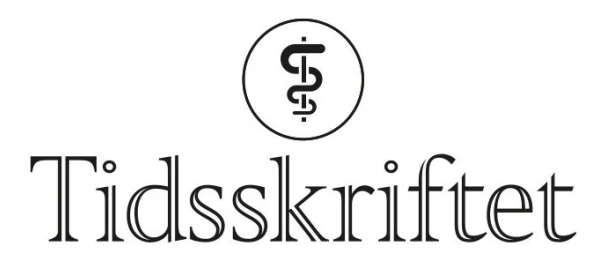

DEN NORSKE LEGEFORENING

\title{
Omega-3-fettsyrer - både mat og medisin
}

LEDER

\section{KJETIL RETTERSTØL}

Kjetil Retterstøl (f. 1962) er spesialist i medisinsk biokjemi. Han har arbeidet ved Lipidklinikken i 20 år, og har det siste året hatt hovedstilling ved Avdeling for ernæringsvitenskap ved Universitetet i Oslo.

Forfatter har fylt ut ICMJE-skjemaet og oppgir følgende interessekonflikter: Han har mottatt foredragshonorar fra MSD, Pfizer, Sanofi, AstraZeneca, Abbot, Novartis og Opplysningskontoret for melk. Han er deltaker i Mills vitenskapelige råd.

Email: kjetil.retterstol@medisin.uio.no

\section{Mange er enig i at fisk er sunt, men hva med det enorme tilbudet av kosttilskudd med omega-3-, omega-6- og omega- 9-fettsyrer?}

La det være sagt med en gang: Vår kropp lager selv omega-9-fettsyrer. Omega-6 får vi i store mengder fra planteoljer. Å kjøpe tilskudd av omega-9 og omega- 6 er derfor bortkastede penger. Men hva med marine omega-3-fettsyrer? For å bevise en effekt er det nå vanlig å kreve dobbeltblinde, placebokontrollerte studier, noe som innebærer betydelige utfordringer når det gjelder kostholdsforskning. For det første: Det er ikke enkelt å lage "placebomat» som både ser likt ut og smaker som «intervensjonsmat». For det andre: Spises mer av noe, spises mindre av noe annet. Da blir det vanskelig å vite hva som gir effekt. En tredje metodologisk utfordring er at resultatet fra studier i ett land ikke uten videre kan anses å være valid i et annet land fordi kostholdstradisjonene er svært varierte. Store metaanalyser har flere ganger, og senest i år, konkludert ulikt: At omega-3 ikke virker (1) eller at det virker (2 2 ). Slike studier dokumenterer i alle fall at metaanalyser er lite egnet til studier av denne problematikken. Kompleksiteten blir for stor fordi omega-3 er både mat og medisin.

Marine omega-3-fettsyrer er et registrert medikament som forskrives i 1 grams kapsler med indikasjonene «behandling av hypertriglyseridemi» og/eller «støttebehandling ved sekundær profylakse etter hjerteinfarkt, i tillegg til annen standard terapi». Det eksemplifiserer hvordan krav til dokumentasjon faktisk kan favorisere kapsler foran mat. Krav om minimal naturlig variasjon er vanskelige å tilfredsstille ved å spise fisk in natura. Om dette gjør at flere velger kapsel heller enn å spise fisk vites ikke, men det er vel verdt å tenke over problemstillingen. 
Omega-3-fettsyrer er essensielle og av dem er eikosapentaensyre (EPA) og dokosaheksaensyre (DHA) mest studert. For voksne personer anbefaler den europeiske matmyndigheten (EFSA) å innta minst o,25 g EPA + DHA per dag (3). Om det er mye eller lite kommer an på øynene som ser, men med $100 \mathrm{~g}$ røkelaks eller makrell i tomat per uke eller en skje vanlig tran (5-10 ml) 2-3 ganger per uke så er du i mål med god margin. To fiskemiddager i uken, f.eks. $150 \mathrm{~g}$ sei en dag og $250 \mathrm{~g}$ torsk en annen dag, dekker også ukesbehovet. Likevel er det mange som tar tilskudd. Omsetningen av omega-3-tilskudd, inklusive tran, var på 689 millioner kroner i 2011 (Turid Backer, Bransjerådet for Naturmidler, personlig meddelelse). Til sammenlikning ble det omsatt statiner for 396 millioner kroner (4). Tatt i betraktning at statiner brukes av $10 \%$ av alle personer i Norge, selges det svært mye omega-3-fettsyrer.

Vitenskapskomiteen for mattrygghet leverte i fjor en rapport der man fant at det gjennomsnittlig samlede inntaket av EPA + DHA i Norge var o,5-0,8 g per dag hos voksne personer som ikke benyttet omega-3-tilskudd (5). Situasjonen i Norge synes altså å være ganske bra i forhold til de anbefalte $0,25 \mathrm{~g}$ per dag. Problemet er at $5 \%$ av dem som ikke tar tilskudd, bare får i seg o,1-0,2 g per dag, noe som er for lite. Også $5 \%$ av barn i alderen 2, 4, 9 og 13 år får for lite omega-3-fettsyrer (5). På den andre siden av skalaen er det slik at $5 \%$ av voksne som bruker omega-3-tilskudd inntar mer enn 5,4-6,o g per dag. Dette er mer enn den maksimalt anbefalte dosen av omega-3-fettsyrer når det gis som et medikament. Spørsmålet er da om det kan bli for mye? Vitenskapskomiteen for mattrygghet konkluderte med at tilgjengelige data ikke tillater fastsettelse av noe øvre tolerabelt inntak av EPA og DHA (5), mens EFSA nylig konkluderte med at inntil 5 g EPA + DHA som ekstra tilskudd per døgn er sikkerhetsmessig akseptabelt (므).

I en artikkel i dette nummer av Tidsskriftet konkluderer Knud Landmark \& Carina S. Alm med at et høyt inntak av fisk og marine omega-3-fettsyrer synes å beskytte mot både utvikling og dødelighet av hjertesvikt (7.). Etter at deres artikkel ble akseptert for publisering, er det imidlertid kommet en ny viktig studie. ORIGIN-studien ( $\underline{8}$ ) sammenliknet $1 \mathrm{~g}$ omega-3 med placebo hos pasienter med høy kardiovaskulær risiko og diabetes eller insulinresistens og fant ingen forskjell i antall kardiovaskulære hendelser eller dødsfall. GISSI-HF-studien (9.), fant imidlertid redusert død ved bruk av omega-3 til pasienter med manifest hjertesvikt. Til sammenlikning har statiner ikke vist effekt på død

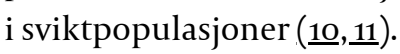

Et viktig budskap fra Landmark \& Alm er derfor at tilskudd med omega-3-fettsyrer gir en sannsynlig tilleggseffekt i en hjertesviktpopulasjon som ellers responderer lite på lipidsenkende terapi. Mye tyder på at omega-3-fettsyretilskudd kan være gunstig ved hjertesvikt. Bør alle slik pasienter få tilskudd med kapsler? Jeg mener nei, det kommer an på kostholdet for øvrig. De som spiser nok omega-3-fettsyrer, trenger selvsagt ikke å ta tilskudd.

Jeg takker Christian A. Drevon for kritisk gjennomlesning av manus.

\section{LITTERATUR}

1. Rizos EC, Ntzani EE, Bika E et al. Association between omega-3 fatty acid supplementation and risk of major cardiovascular disease events: a systematic review and meta-analysis. JAMA 2012;308: 1024-33. [PubMed] [CrossRef]

2. Delgado-Lista J, Perez-Martinez P, Lopez-Miranda J et al. Long chain omega-3 fatty acids and cardiovascular disease: a systematic review. Br J Nutr 2012; 107 (suppl 2): S201-13. [PubMed] [CrossRef]

3. Scientific Opinion on the substantiation of health claims related to EPA, DHA, DPA and maintenance of normal blood pressure (ID 502), maintenance of normal HDL-cholesterol concentrations (ID 515), maintenance of normal (fasting) blood concentrations of triglycerides (ID 517), maintenance of normal LDL cholesterol concentrations (ID 528, 698) and maintenance of joints (ID 503, 505, 507, 511, 518, 524, 526, 535, 537) pursuant to Article 13(1) of Regulation (EC) No 1924/2006. EFSA Journal 2009; 7:1263. 
4. Reseptregisteret. www.reseptregisteret.no/Prevalens.aspx (29.8.2012).

5. Vitenskapskomiteen for mattrygghet. www.vkm.no/dav/c7a41adb79.pdf(29.8.2012).

6. EFSA - European Food Safety Authority. www.efsa.europa.eu/en/efsajournal/pub/2815.htm (29.8.2012).

7. Landmark K, Alm CS. Fisk og omega-3-fettsyrer ved hjertesvikt. Tidsskr Nor Legeforen 2012; 132: 22814 .

8. Bosch J, Gerstein HC, Dagenais GR et al. n-3 fatty acids and cardiovascular outcomes in patients with dysglycemia. N Engl J Med 2012;367:309-18. [PubMed] [CrossRef]

9. Tavazzi L, Maggioni AP, Marchioli R et al. Effect of n-3 polyunsaturated fatty acids in patients with chronic heart failure (the GISSI-HF trial): a randomised, double-blind, placebo-controlled trial. Lancet 2008; 372: 1223-30. [PubMed] [CrossRef]

10. Tavazzi L, Maggioni AP, Marchioli R et al. Effect of rosuvastatin in patients with chronic heart failure (the GISSI-HF trial): a randomised, double-blind, placebo-controlled trial. Lancet 2008; 372: 1231-9. [PubMed] [CrossRef]

11. Kjekshus J, Apetrei E, Barrios V et al. Rosuvastatin in older patients with systolic heart failure. $\mathrm{N}$ Engl J Med 2007; 357: 2248-61. [PubMed] [CrossRef]

Publisert: 30. oktober 2012. Tidsskr Nor Legeforen. DOI:10.4045/tidsskr.12.1006 (C) Tidsskrift for Den norske legeforening 2023. Lastet ned fra tidsskriftet.no 26. april 2023. 